\title{
Instructors' Perceptions of English for Academic Purposes Textbooks at University Level
}

\author{
Thaer Issa Tawalbeh ${ }^{1}$ \\ ${ }^{1}$ English Language Center, Taif University, Taif, Kingdom of Saudi Arabia \\ Correspondence: Thaer Issa Tawalbeh, English Language Center, Taif University, Building No. 7000, P.O Box \\ 888, Zip Code: 21974, Kingdom of Saudi Arabia. Tel: 966-599-234-100. E-mail: rahafthaer2003@gmail.com
}

Received: September 25, 2018

Accepted: October 11, $2018 \quad$ Online Published: November 12, 2018

doi:10.5539/hes.v8n4p153

URL: https://doi.org/10.5539/hes.v8n4p153

\begin{abstract}
The present paper aims to investigate EFL instructors' perceptions of Cambridge English Unlimited (CEU) textbooks taught at Taif University English Language Center (TUELC) in the Academic year 2017-2018. To achieve this purpose, the researcher attempted to answer three questions. The first investigates instructors' perceptions of the textbooks. The second question aims to find out the features that add to the strengths of the textbooks. The third question is an attempt to reveal the shortcomings of the textbooks from the instructors' perspectives and their suggestions to overcome these drawbacks. A questionnaire of 4- Likert scale was used to gather data from ninety two instructors to answer the first two questions, and content analysis was used to answer the third question. The collected data were analyzed in the form of descriptive statistics, using means, standard deviation and percentages. The results showed that instructors have a very positive attitude towards the textbooks in terms of the criteria and features investigated in the first two sections of the study tool. These answer the first two questions. However, they had certain concerns and suggestions in aspects other than those included in the study tool. These have been summarized according to their frequency of occurrence in the instructors' responses. Based on the results, the researcher drew a number of conclusions and recommendations.
\end{abstract}

Keywords: textbooks, textbook evaluation, perceptions, EFL learners and teachers

\section{Introduction and Theoretical Background}

\subsection{Importance of Textbooks}

Textbooks play a significant role in language learning; they are used as an important tool for academic studies (Wang, 2010; Gholami, Nikon \& Soultanpour, 2012). Sheldon (1988) believes that textbooks can serve different purposes for teachers. They are a core resource, a source of supplemented materials, an inspiration for classroom activities and tasks, and the route map of any ELT program in that they provide the objectives of language learning. They function as a lesson plan and working agenda for teachers and learners and they offer considerable advantages, for both the learners and the teachers. The educational philosophy of textbooks affects the class and learning process. In addition, textbooks influence teaching; they help in the process of lesson planning, make available a wide selection of resources and tasks and cover many topics. The great variety of textbooks has led language educators to suggest different criteria for assessing them (Kilickaya, 2004; Olajide, 2003). Guilloteaux (2013) believes that textbooks continue to be a central feature of language classrooms worldwide. Accordingly, their quality can affect the learning experiences of many students. A quality textbook should be a model of good teaching (Newton \& Newton 2009). They should also facilitate students' language learning (Cook 1998; Tomlinson 2008, 2011; Waters 2009).

According to Richards (2001), textbooks are considered as the major source of contact that EFL learners have with the language. They are important resources which help EFL learners to learn English in EFL contexts. Furthermore, Dubin and Olshtain (1986) maintain that textbooks are the tangible factor which provides many teachers and learners with language course face validity.

According to Riazi (2003), textbooks play a very important role in the realm of language teaching and learning as they are the next important factor in the language classroom after the teacher.

Dudley-Evans and St. John (1998) believe that books are important in every learning situation and help teachers with their responsibilities. They are used as a source of language and a learning support. They also help in or 
motivation and stimulation, and are used for reference. In addition, textbooks can help such teachers plan, show what should be in a lesson, present the content in ways which support comprehension and learning, and provide students with learning activities to develop and consolidate that learning (Newton, 1993; Chien \& Young, 2007).

\subsection{Textbook Evaluation}

According to Tomlinson and Masuhara (2001), textbook evaluation enables teachers, supervisors, administrators and materials developers to make judgments about the effect the materials have on the people who use them. Besides, Zohrabi (2011) believes that material evaluation should be the top priority of any curriculum. In addition, as no textbook can be perfect, textbook evaluation is very important to clarify the suitability of the sources and find the best one (Gholami, Nikou, \& Soultanpour, 2012). McDonough and Shaw (2003) believe that textbook evaluation is very useful in that it allows the teachers to choose the best possible book for their language learners.

Nunan (1991) stated that the selection process can be greatly facilitated by the use of systematic materials evaluation procedures which help ensure that materials are consistent with the needs and interests of the learners they are intended to serve, as well as being in harmony with institutional ideologies on the nature of language and learning.

Cunningsworth (1995) emphasized careful selection of materials, and that the materials selected should closely reflect the aims, methods, and values of the teaching program. He maintained that textbooks have the potential to serve as an effective resource for self-directed learning, a resource for presentation of materials, and a syllabus where they reflect pre-determined learning objectives.

Wong (2013) argued that developing or adopting an evaluation checklist can help teachers examine, evaluate and select new textbooks. An evaluation checklist can help ensure that we examine textbooks from several angles.

Many scholars have suggested checklists for a thorough examination of the course book contents, considering a wide range of critical features, such as practical considerations, four-skill balance, exercises and activities, pedagogical analyses, appropriateness in language and grammar, and supplementary materials (Ghorbani, 2011; Mukundan \& Ahour, 2010; Mukundan \& Nimehchisalem, 2012; Tomlinson, 2012; Tsagari \& Sifakis, 2014).

In the case of Taif University English Language Center, English is taught as a foreign language for learners whose mother tongue is Arabic. They learn English for general and academic purposes. Feedback from teachers revealed that it is time to adapt and use a new series that could meet EFL learners' needs and interests and help them learn English through an updated series that follows an integrated approach of language learning. Accordingly, a new English for academic purposes series has been adopted and used at the beginning of the academic year 2017. This Cambridge English Unlimited series needs to be investigated in terms of its potential to meet learners' needs and interests from instructors' points of view. Thus, this paper has been conducted to seek instructors' perceptions of the CEU textbooks which would be of help for the authors in their review process to consider instructors' views of the textbooks.

\subsection{Problem Statement and Objective}

Based on the researcher's professional contact with EFL instructors, it has been noticed that they have certain concerns and sometimes complaints regarding the new English for Academic Purposes (EAP) textbooks used currently. The new series 'Cambridge English Unlimited' has been adopted since the academic year 2017. Many instructors have concerns related to the appropriateness of certain features to the students' level and needs. Others have concerns related to the impact of the textbooks on students' learning and achievement. The researcher believes that it is worthwhile to investigate the instructors' perceptions of the textbooks to find out the areas that need to be revisited so that the textbooks are better able to cater for students' interest and needs.

\subsection{Research Questions}

This paper is an attempt to answer the following questions:

1- What are the EFL instructors' perceptions of the Cambridge English Unlimited (CEU) textbooks?

2- What are the available features that add to the strengths of the CEU textbooks?

3- What are the shortcomings of the textbooks from the instructors' points of view and their suggestions to tackle these drawbacks?

\subsection{Significance of the Study}

The results of this paper will be important to:

- Cambridge University Press to consider the instructors' perceptions of the textbooks and their suggestions that 
may help improve the quality of the textbooks.

- The Quality Assurance and Professional Development Unit in the English language Center to further discuss the instructors' perceptions and suggestions as part of the instructors' professional development.

- EFL practitioners to consider the conclusions and recommendations based on the results of the study to conduct further research.

\section{Review of Related Studies}

Many researchers evaluated the effectiveness of EFL textbooks adapted and used by different educational systems.

Baleghizadeh and Rahimi (2011) evaluated the overall pedagogical value and suitability of the English for the students of Sociology. They investigated the factors of practical concerns, materials in relation to course objective, subject matter, linguistic issues, skills and strategies, variety of tasks and activities, and the layout of materials. The findings indicated that the book, despite having merits, was not very suitable for the sociology course. Kirkgoz (2011) evaluated the English textbooks that have been approved to be used by the Turkish Ministry of National Education in state primary schools after the 2005 curriculum renewal process. The books included were Tripl, Texture English, and Time for English. Findings demonstrated that the textbooks are well designed to serve as agents for curriculum change.

Aghazadeh (2015) evaluated the effectiveness and suitability of the EFL textbooks produced by the Ministry of Education and used in Iranian educational system from teachers' and learners' points of view. The results showed that both the teachers and the learners were not satisfied with the quality of the textbooks in increasing learners' motivation to learn English, in producing pragmatically correct sentences, in increasing learners' fluency in speaking English, in improving learners' language skills, and in engaging the learners in learning about the target language culture.

Hamidi et al., (2016) evaluated two popular English textbooks including New Interchange 2 and Four Corners 3 in order to show their similarities and differences in terms of subject matters, vocabulary, structure, exercise, illustration, and physical make up. The findings of the research revealed that there was no significant difference between the two mentioned textbooks.

Kheirabadi and Alavimoghaddam (2016) evaluated the English textbook "Prospect" series from teachers' point of view and represent experts' recommendations to help the material developers in improving the series. The findings of the research showed that "Prospect" series is evaluated very poor in field of shape and printing quality. Teachers believed that the main pitfall of the books is lacking high quality illustrations which foster students' learning. Although many teachers and practitioners participating in the research have found the new series a considerable step forward, it seems that the series faces some serious shortcomings.

Another set of studies were conducted to evaluate New Interchange 2 and Four Corners 3 textbooks to find out the similarities, differences, usefulness, appropriateness, positive aspects and weak points from teachers' points of view (Razmjoo, 2007; Sahrahgard, Rahimi, \& Zaremooayeddi, 2009; Riasati \& Zare, 2010; Moradi \& Afraz (2013); Roohani, Taheri, \& Poorzangeneh, 2014).

Other studies assessed cultural content in EFL textbook (Liu, 2016; Böcü \&Razi, 2016; Aliabari \& Jamalvandi, 2012). Liu (2016) developed a measurement model for assessing cultural contents in EFL textbooks through the

analytic hierarchy process (AHP) method. Using AHP, the criteria influencing textbook evaluation were identified and their relative importance was weighted. Böcü and Razi (2016) identified elements related to intercultural communicative competence in the textbook series Life at A1 and A2 level published by the National Geographic Learning. Aliabari and Jamalvandi (2012) examined the quality of representation of source, target and other cultures in the ELT textbooks.

Other studies were concerned with selection criteria (Kim and Lee, 2009; Newton and Newton, 2009; Mahmood et al., 2010; Guilloteaux, 2013; Wong, 2013). Kim and Lee (2009) developed selection criteria with high validity and reliability for middle school English textbooks and related materials based on teachers' needs. Initial criteria selecting an English textbook have been proposed based on the analysis of the survey and the analysis. Based on the results of the survey, this study developed different weighing value for different categories of criteria in selecting an English textbook. The results of this study can help the EFL teachers choose an appropriate English textbook, and improve the quality of their English teaching eventually.

Newton and Newton (2009) described a procedure for identifying textbooks which have the potential to support students' reason based understanding and help teachers do likewise. The procedure involves counts of cause and 
purpose clauses in samples of text and the classification of the clauses into groups. This can contribute to the selection of textbooks with the potential to support this kind of understanding and be useful models of practice for teachers.

Mahmood et al., (2010) conducted a study to identify indicators of quality textbooks and developed criteria for review, evaluation and approval of quality textbooks in Pakistan. They adopted Garvin's (1988) framework for quality products as basis for identifying the indicators and Delphi technique was employed to reach to consensus on them. Based on final indicators, textbook evaluation criteria were developed and rubrics for each indicator was developed.

Guilloteaux (2013) conducted a study to outline a procedure for language textbook analysis from the perspective of second language acquisition principles as a preliminary procedure to evaluation for selection. The aim was to provide a tool that allows comparison of the potential of textbooks for supporting students' language learning.

Wong (2013) developed an evaluation checklist to help teachers evaluate textbooks from different angles. She took into consideration linguistic and other content, learner needs, teacher support, and practical considerations.

Other studies focused on a descriptive account of the vocabulary distribution in the textbooks across different frequency-based word lists. They were concerned with the lexical coverage of the text materials (Chen, 2014; Kao, 2014). Another set of studies focused on the changes of readability across different book levels in a series (Chiu, 2010; Lin, 2008; Lo, 2010). Another study assessed the appropriateness of the text difficulty development in a textbook series. Its main aim was to assess the progression of text difficulty in different textbook series in Taiwan, the rationale of which is argued to be generalizable to other ELT contexts (Chen, 2016).

In conclusion, the studies reviewed above were conducted to evaluate textbooks to show their effectiveness, to analyze content, or to develop or adopt selection criteria. They were conducted on a variety of textbooks using tools relevant to the context under investigation. However, this study aims at identifying EFL instructors' perceptions of textbooks introduced in the academic context of teaching English as a foreign language at TUELC in the academic year 2017. Instructors were also asked to identify the features that add to the strengths of the textbooks. Meanwhile, they were asked to identify shortcomings they may experience while teaching the newly introduced series. Being new textbooks, it is worthwhile to investigate their impact in terms of meeting learners' interests and needs.

\section{Method}

In this section, the researcher describes the methodology followed to collect and analyzes data. It shows how population and sample of the study were identified, how validity and reliability of the study instrument was checked, procedures followed to conduct the study, and statistical analysis used to analyze the data.

\subsection{Population and Sample Selection}

The study population comprised ninety two EFL instructors teaching English in the English Language Center at Taif University in the second semester of the academic year 2017-2018. Ninety two instructors responded to the questionnaire. This represents almost $50 \%$ of the whole population.

\subsection{Study Instrument}

The researcher developed the questionnaire after reviewing related literature to find a tool to be used for evaluating the EFL instructors' perceptions of CEU textbooks. A 4- Likert scale was used to investigate the EFL instructors' perceptions, strong features and shortcomings of the series (Appendix A)

\subsection{Instrument Validity and Reliability}

To check the instrument validity, five EFL specialists were kindly requested to check if the items were appropriate and relevant to the domains and context. To check the instrument reliability, the checklist was distributed to $20 \mathrm{EFL}$ instructors. They were asked to respond to the questionnaire. It was then distributed to them again after two weeks. The results were analyzed and the correlation coefficient (Pearson) between the previous and post time was 0.87 . The Cronbach alpha reliability for the checklist was .86 .

\subsection{Study Procedures}

The researcher formally requested the approval of the English Language Center director to conduct the study and distribute the questionnaire to the instructors. The instrument was checked for validity and reliability. Having the consent of the participants, the questionnaire was distributed and collected after being filled in. The researcher processed the results using the appropriate statistical methods. Based on the findings, relevant conclusions and recommendations were drawn. 


\subsection{Statistical Analysis}

Descriptive statistical analysis was used to answer the first two questions which aimed to investigate EFL instructors' perceptions and strong features of the CEU series. This includes the use of means, standard deviation and percentages. Content analysis was used to answer the third question which aims to identify the instructors' points of view regarding the shortcomings of the textbooks and their suggestions to deal with the shortcomings.

\section{Results and Discussion}

To answer the first question related to the instructors' perceptions of the textbooks, Table 1 shows means, standard deviation and percentages of the instructors' points of view.

\section{Key: 1= Agree $\quad$ 2= Strongly Agree $\quad 3=$ Disagree $\quad 4=$ Strongly Disagree}

Table 1. Mean, standard deviation and percentages of the instructors' perceptions of the textbooks

\begin{tabular}{llcccc}
\hline & \multicolumn{1}{c}{ Criteria } & Mean & Std. Deviation & \multicolumn{2}{c}{ Percentages } \\
\cline { 5 - 6 } No. & & & & Agree & Disagree \\
\hline 1 & There is a balance of skills. & 1.54 & .79 & $88 \%$ & $12 \%$ \\
2 & The book is the right length. & 1.66 & .90 & $79.4 \%$ & $20.6 \%$ \\
3 & The book is culturally appropriate. & 1.56 & .78 & $88 \%$ & $12 \%$ \\
4 & The visual material is useful. & 1.40 & .64 & $95.6 \%$ & $4.4 \%$ \\
5 & The methodology is appropriate. & 1.50 & .71 & $89.2 \%$ & $10.8 \%$ \\
6 & The textbook helps prepare learners & 1.71 & .95 & $78.2 \%$ & $21.8 \%$ \\
& for their end-of-year exams. & & & & \\
7 & The topics of the texts are up-to-date. & 1.39 & .61 & $95.6 \%$ & $4.4 \%$ \\
8 & Language dealt with is in a learner-centered way & 1.48 & .71 & $89.1 \%$ & $10.9 \%$ \\
9 & Related media can be exploited? & 1.57 & .81 & $85.9 \%$ & $14.1 \%$ \\
& (CDs, DVDs, online worksheets) & & & & \\
10 & The teacher's book is helpful. & 1.52 & .61 & $93.4 \%$ & $6.6 \%$ \\
\hline
\end{tabular}

It is clear from the table above that the majority of instructors agree on each of the criterion stated to evaluate their perceptions of CEU textbooks. This positive feedback of the instructors' could be explained on the ground that the textbooks have been developed by experts who fulfilled major evaluation criteria stated in the table above, and that these should be included in an EFL textbook that is expected to meet the basic interests and needs of EFL learners.

To discuss the second question related to the features that add to the strengths of the textbooks, tables 2 shows percentages of the strong features of the textbooks.

Table 2. Percentages of the strong features of the textbooks

\begin{tabular}{llcc}
\hline No. & \multicolumn{1}{c}{ Features } & \multicolumn{2}{c}{ Percentages } \\
\cline { 3 - 4 } & & Yes & No \\
\hline 1 & The textbook includes a grammar reference section. & $94.6 \%$ & $5.4 \%$ \\
2 & There is a vocabulary reference section at the end of the textbook book or units. & $90.2 \%$ & $9.8 \%$ \\
3 & The textbook includes regular review sections. & $93.5 \%$ & $6.5 \%$ \\
4 & The textbook includes pronunciation sections. & $94.6 \%$ & $5.4 \%$ \\
5 & The textbook includes extra activities. & $93.5 \%$ & $6.5 \%$ \\
6 & The teacher's book includes progress tests. & $94.6 \%$ & $5.4 \%$ \\
7 & The workbook provides relevant further practice. & $94.6 \%$ & $5.4 \%$ \\
\hline
\end{tabular}

It is clearly evident that most of the instructors agree that the textbooks include all the features stated in the above table. The features relate to facts that are either available or not available in the textbooks. The majority of instructors have a very positive judgment of the textbooks when evaluated according to the criteria stated above. Accordingly, these features add to the strengths of the textbooks adopted and taught for academic purposes. These features were investigated to see if the instructors are aware of them all through the textbooks as they are helpful for them when planning, implementing and assessing the learners' achievement.

In order to investigate the instructors' views of the textbooks in aspects other than those included in the study tool, the third question came to see if there are any shortcomings the instructors experienced while using the textbooks and their suggestions to overcome the drawbacks. The instructors' responses, summarized according to their frequency, came as follows: 
- texts should focus more on topics that meet the learners' needs and interests. These include relationships, entertainment, gadgets, social media, fashion, and others that can be included based on assessing learners' needs.

- font size is not appropriate in many of the texts for the learners' age level.

- more listening tasks should be provided, and should be graded in length as the majority are too short especially in book 1 .

- more space should be provided in the textbooks for learners to write in their responses.

- there should be more grammar activities and further explanation for the grammar activities for learners to go back to for more clarification.

- there should be more focus on authentic texts and audios.

- the teacher's book should include progress tests.

- In some of the audio tracks, learners listen to a man or a woman of a certain nationality, but the provided pictures show a different nationality.

- There should more focus on vocabulary-based activities.

\section{Conclusions and Recommendations}

The present paper aimed to investigate EFL instructors' perceptions of CEU textbooks used to teach EFL for academic purposes at Taif University English Language Center, and provide suggestions to overcome potential shortcomings instructors encounter while using the textbooks. The results revealed that the majority of instructors have a very positive attitude towards the textbooks. They believe that the textbooks meet the criteria adopted in the first section of the study tool, and there are features that add to the strength of the textbooks, which have been included in the second section of the study tool (Appendix A). However, the instructors raised some concerns they experienced while teaching the textbooks while answering the third question of the study. These were summarized at the end of the results section of the study based on their frequency of occurrence in the instructors' responses. The Quality Assurance and Development Unit in the English Language Center is recommended to consider the instructors' concerns towards the textbooks. It may form a committee to study their concerns and report the results to the authors of the textbooks to consider in their review process.

\section{Implications for Future Research}

The results of this study have implications for the authors of the textbooks, the Quality Assurance and Development Unit in the English Language Center and EFL practitioners. The research is timely in the sense that it would be helpful for the authors to consider the instructors' concerns and suggestions in the review process of the textbooks. As for the Quality and Development Unit, it would be beneficial to hold a professional development session where the instructors can further discuss and share experiences of the textbooks in terms of their positive aspects and those that need further consideration. As the present paper investigated only the instructors' perceptions of the textbooks, EFL practitioners may further investigate EFL learners' perceptions of the textbooks and seek their needs when studying an English textbook for academic purposes.

\section{Acknowledgments}

The researcher would like to acknowledge the contribution of the instructors who participated in the questionnaire validity and reliability. Many thanks also go to the instructors who responded to the questionnaire.

\section{References}

Aghazadeh, Z. (2015). An Evaluation of High School English Textbooks in Iranian EFL Context: Teachers' versus Learners' Perceptions. Journal of Language Teaching and Research, 6(5), 1115-1124. https://doi.org/10.17507/jltr.0605.26

Aliabari, M., \& Jamalvandi, B. (2012). Realization of Culture in English Textbooks in Chinese High School Level. Journal of Pan- Pacific Association of Applied Linguistics, 16(2), 89-100.

Baleghizadeh, S., \& Rahimi, A. H. (2011). Evaluation of an ESP Textbook for the Students of Sociology, Journal of Language Teaching and Research, 2(5), 1009-1014. https://doi.org/10.4304/jltr.2.5.1009-1014

Böcü, A., \& Razı, S. (2016). Evaluation of textbook series 'Life' in terms of cultural components, Journal of Language and Linguistic Studies, 12(2), 221-237.

Chen, H. (2014). A study on vocabulary selection in senior high school textbooks in Taiwan from the perspective of the academic word list (Unpublished master's thesis). Taipei, Taiwan: National Taiwan Normal University. 
Chen, A. (2016). A critical evaluation of text difficulty development in ELT textbook series: A corpus-based approach using variability neighbor clustering, System, 58(1), 64-81. https://doi.org/10.1016/j.system.2016.03.011

Chiu, C.-A. (2010). Readability analysis and curriculum coherence of dialogues and reading passages in English textbooks for junior high schools in Taiwan (Unpublished master's thesis). Taichung, Taiwan: National Taichung University of Education.

Chien, C. C., \& Young, K. (2007). The centrality of textbooks in teachers' work: Perceptions and use of textbooks in a Hong Kong Primary School. The Asia-Pacific Education Researcher, 16(2), 155-164.

Cook, V. (1998). Relating SLA research to language teaching materials. Canadian Journal of Applied Linguistics, l(1-2), 9-27.

Cunningsworth, A. (1995). Choosing your coursebook. Oxford: Heinemann.

Dubin, F., \& Olshtain, E. (1986). Course design. Developing programmers and materials for language learners. Cambridge: Cambridge University Press.

Dudley-Evans, T., \& St. John, M. J. (1998). Developments in English for specific purposes: A multi-disciplinary approach. Cambridge: Cambridge University Press.

Gholami, J., Niko, F., \& Soultanpour, A. (2012). A retrospective-comparative evaluation of textbooks developed by native and non-native English speakers, Journal of Academic and Applied Studies, 2(11), 35-42.

Ghorbani, M. R. (2011). Quantification and graphic representation of EFL textbook evaluation results. Theory and Practice in Language Studies, 1(5), 511-520. https://doi.org/10.4304/tpls.1.5.511-520

Garvin, D. A. (1988). Managing Quality: The Strategic and Competitive Advantage. New York: Free Press.

Guilloteaux, M. (2013). Language Textbook Selection: Using Materials Analysis from the Perspective of SLA Principles, Asia-Pacific Edu Res., 22(3), 231-239. https://doi.org/10.1007/s40299-012-0015-3

Hamidi, H., Bagheri, M., Sarinavaee, M., \& Seyyedpour, A. (2016). Evaluation of Two General English Textbooks: New Interchange 2 vs. Four Corners 3, Journal of Language Teaching and Research, 7(2), 345-351. https://doi.org/10.17507/jltr.0702.13

Kao, Y.-C. (2014). A corpus analysis of word frequency lists and lexical coverage for senior high school English textbooks and the reading comprehension tests of JCEE (Unpublished master's thesis). Taipei, Taiwan: National Taiwan University of Technology.

Kheirabadi, R., \& Alavimoghaddam, S. B. (2016). Evaluation of Prospect Series: A Paradigm Shift from GTM to CLT in Iran. Journal of Language Teaching and Research, 7(3), 619-624. https://doi.org/10.17507/jltr.0703.26

Kilickaya, F. (2004). Guidelines to evaluate cultural content in textbooks. The Internet TESL Journal, 10(12), $38-48$.

Kim, J. R., \& Lee, Ji-Eun. (2009). Developing selection criteria for middle school English textbook. English Teaching, 64(2), 3-28. https://doi.org/10.15858/engtea.64.2.200906.3

Kirkgoz, Y. (2011). An evaluation of English textbooks in Turkish primary education: Students' and teachers' perceptions, Eurasian Journal of Educational Research, 44(1), 167-184.

Lin, J.-F. (2008). Comparisons of the readability among the six versions of English textbooks in junior high school in Taiwan (Unpublished master's thesis). Kaohsiung, Taiwan: National Kaohsiung Normal University.

Liu, K. (2016). Prioritizing criteria for evaluating cultural contents in EFL textbooks through AHP, Journal of Language Teaching and Research, 7(5), 841-850. https://doi.org/10.17507/j1tr.0705.03

Lo, L. W. (2010). Comparative analysis of the readability of the reading passages in senior high school English textbooks (Unpublished master's thesis). Hsinchu, Taiwan: Hsuan Chuang University.

Mahmood, K., Iqbal, M. Z., \& Saeed, M. (2010). Textbook Evaluation Through Quality Indicators: The Case of Pakistan, Bulletin of Education and Research, 2(31), 1-27.

McDonough, J., \& Shaw, C. (2003). Materials and methods in ELT: A teacher's guide. Malden, MA: Blackwell Publishing Ltd. 
Moradi, A., Karbalaee, A. R., \& Afraz, S. (2013). A textbook evaluation of speech acts and language functions in high school English textbooks (I, II, and III) and Interchange series, books I, II, and III. European Online Journal of Natural and Social Sciences, 2(2), 323-335.

Mukundan, J., \& Ahour, T. (2010). A review of textbook evaluation checklists across four decades (1970- 2008). In B. Tomlinson, and H. Masuhara (Eds.), Research for materials development in language learning: Evidence for best practice (336-352). London, UK: Continuum.

Mukundan, J., \& Nimehchisalem, V. (2012). Evaluative Criteria of an English language textbook evaluation checklist, Journal of Language Teaching and Research, 3(6), 1128-1134. https://doi.org/10.4304/jltr.3.6.1128-1134

Newton, D. P. (1993). Teaching packages and their evaluation through a surrogate teacher model. Educational and Training Technology International, 30(1), 375-385. https://doi.org/10.1080/0954730930300408

Newton, D. P., \& Newton, L. D. (2009). A procedure for assessing textbook support for reasoned thinking. The Asia Pacific Education Researcher, 18(1), 109-115. https://doi.org/10.3860/taper.v18i1.1039

Nunan, D. (1991). Language teaching methodology: A textbook for teachers. London: Prentice Hall.

Olajide S. B. (2003). An evaluation of Longman's "New Practical English". Nigerian Journal of Educational Foundations, 6(1), 92-100.

Razmjoo, S. A. (2007). High school or private institutes text books? Which fulfill communicative language teaching principles in the Iranian context? Asian EFL Journal, 9(4), 126-140.

Riasati, M. J., \& Zare, P. (2010). Textbook evaluation: EFL teacher's perspectives on new Interchange. Studies in Literature and Language, 1(8), 54-60.

Riazi, A. M. (2003). What textbook evaluation schemes tell us? A study of the textbook evaluation schemes of three decades. In W. A. Renandya. (Ed.), Methodology and materials design in language teaching (52-68). Singapore: SEAMEO Regional Center.

Richards, J. C. (2001). Curriculum development in language teaching. Cambridge: Cambridge University Press. https://doi.org/10.1017/CBO9780511667220

Roohani, A., Taheri, F., \& Poorzangeneh, M. (2014). Evaluating Four Corners textbooks in terms of cognitive processes using Bloom's revised taxonomy. Research in Applied Linguistic Studies, 4(2), 51-67.

Sahragard, R., Rahimi, A., \& Zaremoayeddi, I. (2009). An in-depth evaluation of interchange series (3rd edition). Porta Linguarum, 12(1), 37-54.

Sheldon, L. E. (1988). Evaluating ELT textbooks and materials. ELT Journal, 42(4), 237-246. https://doi.org/10.1093/elt/42.4.237

Tomlinson, B., \& Masuhara, H. (2001). Adults EFL courses. ELT Journal, 55(1), 80-101. https://doi.org/10.1093/elt/55.1.80

Tomlinson, B. (2008). Language acquisition and language learning materials. In B. Tomlinson (Ed.), English language learning materials: A critical review (3-13). London: Continuum.

Tomlinson, B. (2011). Introduction: Principles and procedures of materials development. In B. Tomlinson (Ed.), Materials development in English teaching (2nd ed., 1-34). Cambridge, UK: Cambridge University Press.

Tomlinson, B. (2012). Materials development for language learning and teaching. Language Teaching, 45(2), 143-179. https://doi.org/10.1017/S0261444811000528

Tsagari, D., \& Sifakis, N. C. (2014). EFL course book evaluation in Greek primary schools: views from teachers and authors. System, 45, 211-226. https://doi.org/10.1016/j.system.2014.04.001

Wang, H. (2010). The end of the revolution: China and the limits of modernity. London: Verso.

Waters, A. (2009). Advances in materials design. In M. H. Long and C. J. Doughty (Eds.), Handbook of language teaching (311-326). Malden, MA: Blackwell.

Wong, R. M. (2013). Developing Criteria for Textbook Evaluation, TESL Reporter, 4(1), $52-74$.

Zohrabi, M. (2011). Coursebook development and evaluation for English for general purposes course. English Language Teaching, 4(2), 213-222. https://doi.org/10.5539/elt.v4n2p213 


\section{Appendix A}

Dear instructors,

The researcher will carry out a study to investigate instructors' perceptions of the English for Academic Purposes 'Cambridge English Unlimited' textbooks they use. For this purpose, the researcher seeks your points of view by filling in the questionnaire below.

Please note that your contribution will be used for research purposes only.

The researcher

Section A: Your perceptions of the textbooks

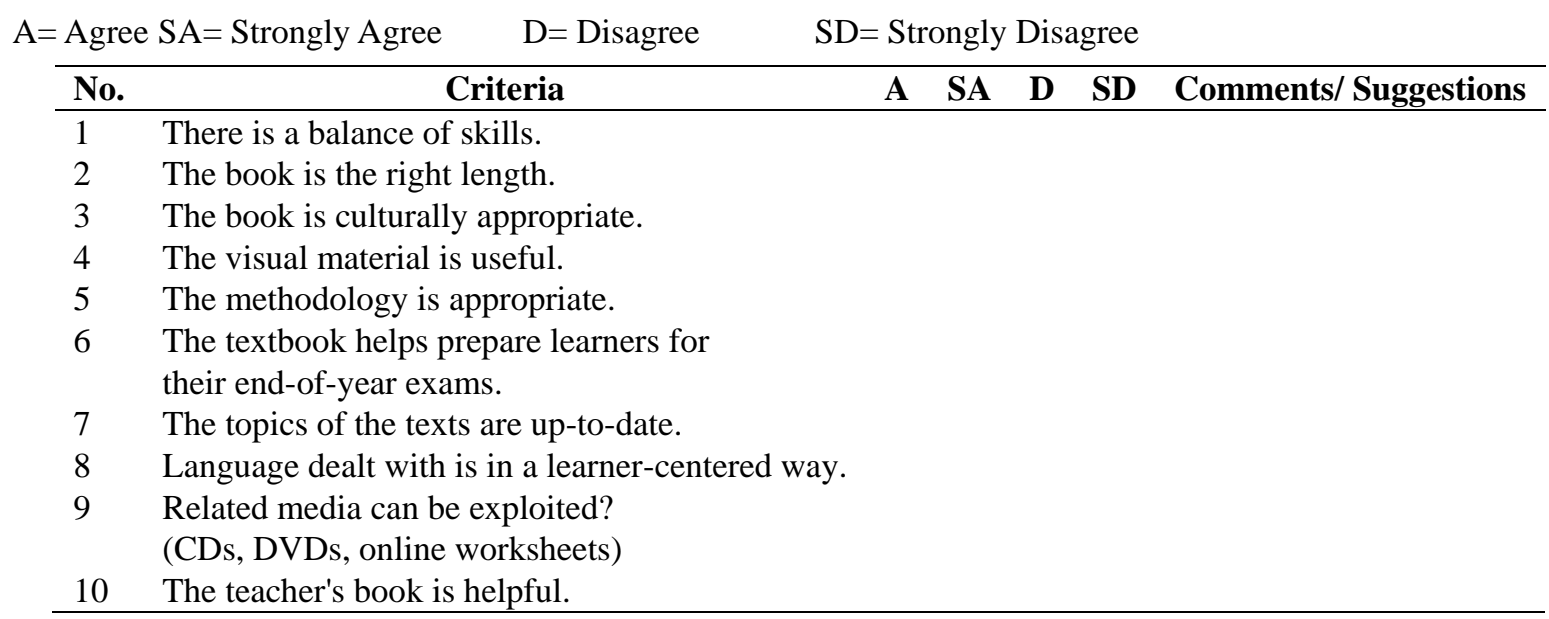

Section B: Features that add more strengths to the textbooks

\begin{tabular}{|c|c|c|c|c|}
\hline No. & Criteria & Yes & No & Comments/ Suggestions \\
\hline 1 & The textbook includes a grammar reference section. & & & \\
\hline 2 & $\begin{array}{l}\text { There is a vocabulary reference section at the } \\
\text { end of the textbook book or units. }\end{array}$ & & & \\
\hline 3 & The textbook includes regular review sections. & & & \\
\hline 4 & The textbook includes pronunciation sections. & & & \\
\hline 5 & The textbook includes extra activities. & & & \\
\hline 6 & The teacher's book includes progress tests. & & & \\
\hline 7 & The workbook provides relevant further practice. & & & \\
\hline
\end{tabular}

Section C

Please list the shortcomings of the textbooks and your suggestions to deal with the drawbacks.

\section{Copyrights}

Copyright for this article is retained by the author(s), with first publication rights granted to the journal.

This is an open-access article distributed under the terms and conditions of the Creative Commons Attribution license (http://creativecommons.org/licenses/by/4.0/). 